\title{
The Man Who Made His Own Eve
}

\section{Stephen Bertman, West Bloomfield, MI, USA}

Tortured by an incurable skin disease, the medieval Hebrew poet and philosopher, Solomon Ibn Gabirol [c. 10211070?], is said to have created a female golem, or robot, to ease his loneliness and suffering. "The Man Who Made His Own Eve," recounts the story of Gabirol's incredible invention and the personal and tragic consequences of his daring.

Clutching the blood orange in his fist, the anguished poet stared at its smooth rind. "Can I ever escape the ugliness of my own skin?" he cried. "Can I ever flee from the fevered pain of my flesh? Each day I grow thinner as my body wastes away. My soul remains trapped, tortured by its yearning for God. Yet, despite my prayers, death refuses to release me so I can find Him."

So spoke the Jewish poet-philosopher Solomon Ibn Gabirol ten centuries ago as he sat in the darkness of his bedroom. Outside, the Spanish sun shone radiantly, warming the fertile earth and the groves of orange trees that surrounded his house. But should he venture outside, that selfsame sun would burn his lesioned skin.

Frustrated, he slashed his knife though the orange's rind and, as his grip slipped, he cut his hand with the blade, causing the fruit's red juice to spurt out and blend with the blood that oozed from his palm.

Solomon was only in his twenties, but had been cursed with a rare skin disease for as long as he could remember, though his disfigurement and its pain had grown worse in recent months. Every household task, it seemed, took more and more effort and, while he had hired servants to help him, one after the other they had left, fearing the leprosy-like contagion they might contract.

Medicinal powders and ointments were of no avail and so, in desperation, the aching sage reached out to the ancient parchment scrolls on his library's shelves in the hope of discovering some miraculous cure.

In his copy of the Talmud he read: "If the righteous desire it, they can create whole worlds." "Not just worlds," he suddenly realized, "but human beings too." Excited in this realization, he pulled down from its shelf a well-worn copy of the Sefer Yetzirah, the mystical Book of Creation that described how God had created the universe by using only the power of His voice to name the things He wished to exist.

Women in Judaism: A Multidisciplinary Journal Volume 17 Number 1 (2020) ISSN 1209-9392 
Poring over the fragile pages of the book, Solomon read how a righteous man might duplicate the divine act of creation. The 22 letters of the Hebrew alphabet had emanated from the four potent letters, YHWH, that spelled out God's name. By choosing the right letters of the alphabet and reciting them in the correct order, the book said, a righteous man could will things into existence.

That Solomon was righteous there was no doubt. The pious prayers he had continually uttered and the majestic psalms he had composed to praise God had demonstrated this time and time again. Perhaps, he reasoned, by uttering the right letters of the alphabet with holy intent, he could create another human being, perhaps even a woman to be his compassionate helpmate just as God had created Eve to help Adam. Only in this case Adam would create his own Eve. Could this selfish purpose, he wondered, excuse his use of such awesome mystical power? The insistent pain in Solomon's flesh gave him the only answer he could accept.

According to the second chapter of Genesis (2:22), God had created Eve with the aid of Adam's rib, but in no way could Solomon remove a rib from his own side to replicate that feat. However, according to the very first chapter of Genesis (1:27), God appeared to have created an earlier wife for Adam, an unnamed one he molded simultaneously from the very same earth he had used to make Adam.

Scholars of scripture had long debated this seeming contradiction between the Torah's first two chapters, concluding that Adam's first wife had become unhappy with being sexually subservient to her husband, and left him, thus making way for Eve. They called Adam's first wife Lilith, meaning "a creature of night", and derided her as a willfully disobedient and lustful demon. Solomon trembled at the thought of unleashing another such Lilith on his own life.

To make his Eve, Solomon began by shaping the warm, moist soil of his orchard into the form of a woman. He began on the sixth day of the week just as God had done when he created the world's first human beings. "My own Garden of Eden," he murmured to himself as he labored.

And then, before the sun set, he lit two olive-oil-filled Sabbath lamps, one for himself and one for his Eve and, instead of voicing the usual Sabbath prayer, uttered the mystical alphabetic incantation he had learned. On the seventh day, just as God had done in Genesis, Solomon rested. 
Outside in the chill January wind, the Andalusian olive trees stood like squat, twisted skeletons. But inside, where a fire blazed on the hearth, the air was warm. Solomon sat close by the logs, holding his hands out toward the flames. A dark-skinned young woman sat beside him, draped in a modest shawl, her delicate profile illuminated by the orange firelight. They did not speak much - she had only recently learned his language - but words were not as important as her comforting presence. As they sat there together, she gently rested her hand on his arm, an arm whose skin had miraculously begun to heal.

Solomon's neighbors, as the story goes, had already begun to gossip about her: who she was or, more seriously, what she was. The poet already had his share of enemies, literary rivals whose petty jealousies were spurred by his undeniable talent and pride in his craft, a brittle pride born of irritability that bordered on arrogance. But added to those critics, whom Solomon dismissively derided as mere chirping grasshoppers, were others of a more common and dangerous sort who whispered that this mysterious woman, who had seemingly come out of nowhere, was somehow a product of the philosopher's dabbling in arcane arts. "Even Gardens of Eden," he soberly reflected, "have serpents to spoil their perfection." Eventually, choosing the chief rabbi of Granada as their spokesman, Solomon's neighbors issued him an ultimatum: rid yourself of that woman, or leave the city for good.

When a delegation of those neighbors arrived at Ibn Gabirol's house the next day, it is said, they found on his doorstep some clay and a pile of cut branches and twigs wrapped in an old woman's dress, the materials from which, they concluded, Gabirol's magic had fashioned a female automaton, or golem, to serve as housekeeper. Their satisfaction was all the more complete when they found that Solomon himself had packed up and left town. One man even claimed to have seen the poet boarding a ship bound for Valencia in the company of another passenger.

Months later, the Jewish community of Granada received the unexpected news that Solomon Ibn Gabirol had inexplicably vanished from his place of exile. Legend records that, in the years that followed, fruit-growers in Valencia marveled at a peculiar fig tree that, unlike other kindred trees in its orchard, produced extraordinarily fragrant blossoms and uncommonly sweet fruit. Puzzled at the cause and seeking an explanation, a curious gardener dug deep into the soil to inspect 
the tree's root system. It was then that, beneath the roots, he uncovered a rude grave containing the corpse of Solomon Ibn Gabirol. Judging by the wounds still visible on the poet's butchered body, he had been murdered, some would say by a rival poet who then hid the evidence of his crime. It was the flesh of that body and, more than that perhaps, its vital spirit that would nourish the tender sapling later planted over it. Close by Solomon's corpse, it is said, the remains of a woman were also found. Her identity is unknown.

For further information on the life and works of Solomon Ibn Gabirol see Gershom Scholem, On the Kabbalah and Its Symbolism, trans. Ralph Manheim (New York: Schocken Books, 1965), 199; Raphael Loewe, Ibn Gabirol (London: Peter Halban, 1989; New York: Grove Press, 1991); and Sarah Pessin, "Solomon Ibn Gabirol [Avicebron\}" (with extensive bibliography) in The Stanford Encyclopedia of Philosophy (https://plato.stanford.edu/entries/ibn-gabirol). For English translations of Ibn Gabirol's poetry see Raymond P. Scheindlin, Vulture in a Cage (Brooklyn, NY: Archipelago Books, 2016), featuring the original Hebrew on opposite pages, and Peter Cole, Selected Poems of Solomon Ibn Gabirol (Princeton, NJ: Princeton University Press, 2001). 